\title{
BASIS OF BIOMASS GRINDERS SUSTAINABLE DESIGNING
}

doi: $\quad 10.2478 /$ czoto-2019-0069

Date of submission of the article to the Editor: 09/11/2018

Date of acceptance of the article by the Editor: 22/12/2018

Weronika Kruszelnicka ${ }^{1}$ - orcid id: 0000-0002-9909-5112

Andrzej Tomporowski ${ }^{1}$ - orcid id: 0000-0002-9860-8748

Józef Flizikowski ${ }^{1}$ - orcid id: 0000-0001-7264-7776

Robert Kasner ${ }^{1}$ - orcid id: 0000-0001-6866-4741

Joanna Cyganiuk ${ }^{2}$ - orcid id: 0000-0002-7279-0692

${ }^{1}$ University of Science and Technology in Bydgoszcz, Poland, weronika.kruszelnicka@gmail.com

${ }^{2}$ University of Zielona Góra, Poland

Abstract: Grinding operations are one of the most commonly used preparation processes in many branches, for example in food, energy and chemical sectors. This paper focuses on the issues connected with design of technical objects in accordance with sustainable development assumptions. The aim of this study is to create methodology of sustainable design of grinding machine, including external influences involved in their operation, to increase safety, energy, economic and eco- efficiency. The problem formulated as a question: what techniques, equipment, methods, and ways should be used in design to obtain a new, better grinder structure? To resolve the problem, original methodology of sustainable design has been created.

Keywords: sustainable designing, grinding, safety, efficiency

\section{INTRODUCTION}

Priorities of the contemporary world set out in strategic development reports of the EU play an important role in intelligent development of construction and development of biomass multi-disc grinding. They provide the basis for energy consumption and $\mathrm{CO}_{2}$ emission reduction. These are (He et al., 2019; Silvestre and Tîircă, 2019; Zhou et al., 2018):

- intelligent development (ID): development of knowledge based economy and innovation,

- sustainable development (SD): supports effective economy using more environment friendly and competitive resources,

- social integration supportive development (SISD): supporting high employment level economy to provide social and territorial coherence.

Although the two remaining kinds of development are characterized by many positive aspects, this is the intelligent development which forms the basis for safer grain biomass grinders operation and maintenance (Zhou et al., 2018). 
Structural and technological solutions available for grinding systems are still ineffective and they fail to solve significant problems such as: high energy costs, low capacity and efficiency and insufficient quality of the final product defined by granulometric characteristics (Flizikowski et al., 2015b; Napier-Munn, 2015; Tomporowski et al., 2017). Attempts to solve the respective problems should be made as early as at the design stage of the grinding system considering the priorities of the economic- social environment (ID, SD, SISD) when the relations between structural features of grinders and the process parameters should be taken into account. These including: linear, angular velocity of the cutting, pressing, grinding edges, material feed speed, energy consumption, power input, etc. as well as the effects of operation measured by means of the following indexes: index of quality (e.g. fineness degree), energy efficiency (e.g. specific energy use), ecological (e.g. emission indexes), economic (e.g. operation costs) (Macko et al., 2016; Wołosiewicz-Głąb et al., 2017). In the light of the above, the study goal is to develop an original methodology for sustainable design of a grinding machine, including the external impacts on its operation, in order to increase its economic, energy and ecological efficiency. The research problem was formulated in the form of the following question: what methods, tools, and technologies should be used in design of a grinder to provide a new, better structure of the grinding mill? In order to solve this problem a new original methodology for sustainable design has been developed.

\section{THE GRINDER DESIGN PROCESS}

Technical design as a process that contributes to obtainment of the final product is referred to as a number of activities that make up a 'recipe' for its creation. Three basis stages can be distinguished in a design of biomaterials grinder, particularly grain biomass:

- STAGE I - conception, providing a concept to be used for a problem solution, e.g. through matching significant geometric, material, technological features, etc.,

- STAGE II - verification of the solution for strength and stiffness, according to current requirements and norms,

- STAGE III - compatibility of modules: process module, control module and logistic module,

- STAGE IV - creation of the design documentation.

The most important stages of a design, from the point of view of the grinder future operation and applicability, are the first stages of the design process. This is when the solution. which is supposed to have the biggest impact on the grinding process parameters and its efficiency indexes, is being developed.

The design process of grinding machines and devices needs to take into account numerous factors such as: functional factors regarding the whole life cycle as well as other external conditions. Figure 1 shows accurate characteristics of the factors included in the process of design of innovative systems for grinding.

These factors can also be divided into: external ones, e.g. for the market needs, application of the grinder, properties of the feed material, manufacturing possibilities, established technological parameters, as well as internal factors e.g. those which utilize relations of particular elements, design methods, tools, algorithm calculation errors, human factors. Figure 2 shows a scheme of the relations between the design related factors in the process of a product manufacturing. 


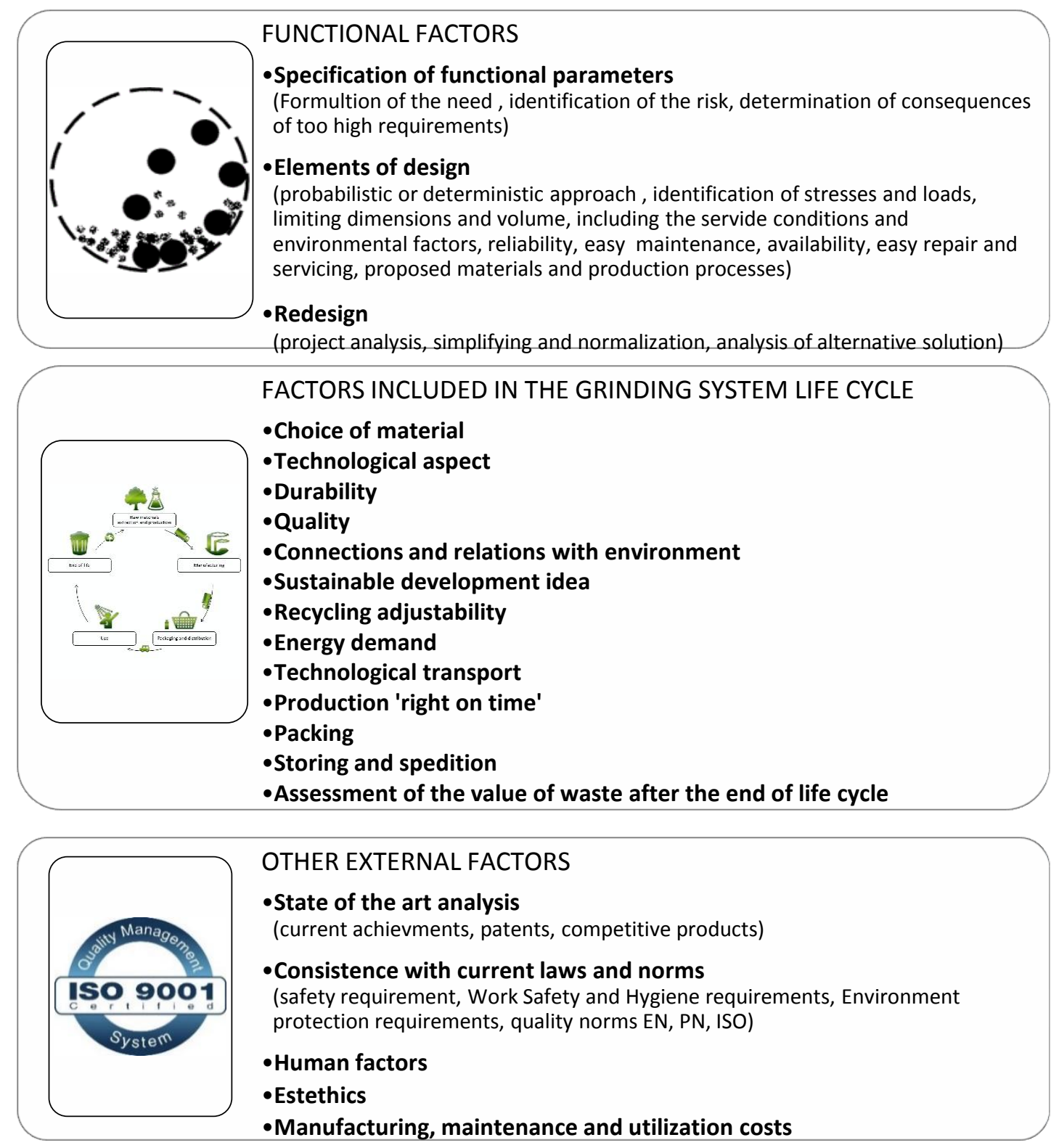

Fig. 1. Factors that affect the process grinding systems design. Own work on the basis of (Kwiatkowski, 2017)

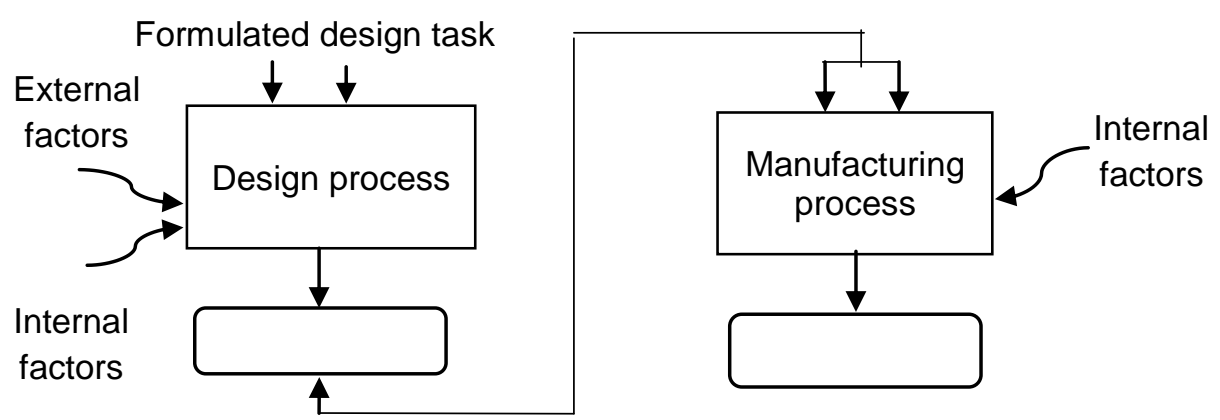

Fig. 2. Scheme of relations between the design factors in the process of the product manufacturing

In general, design refers to many aspects of creation, hence, three types of design can be distinguished (Kwiatkowski, 2017): structural design- it refers primarily to 
design of geometric, strength features; material design - design with respect to materials properties and their selection, technological design - in the scope of manufacturing technology, mode of operation. The above aspects depend largely on each other, they cannot be viewed separately without being familiar with the assumptions.

Earlier studies provided information on postulated operational states of biological fibrous materials grinding, including bio-media energy: quality, efficiency, nondestructiveness. the process quality is affected by the design-construction stage and the manner of its management as well as the operators, customer service staff and the customer, recipient of the final product -power plants or individual clients in the case of energy materials grinding (Flizikowski et al., 2015b; Flizikowski et al., 2017; Fuerstenau and Abouzeid, 2002; Jeswiet and Szekeres, 2016).

Production of an adequate quality product, while keeping efficiency and nondestructiveness, requires development of a thorough and consistent design procedure and constant control of the process and product parameters for structural changes to be introduced while designing (Dabbour et al., 2015; Pan et al., 2007). Control and verification of data is a necessary element of quality improvement of the process itself as well as its output - a grinding machine. The most important quantities which should affect assessment of the structure in the process of design are: temperature changes in working elements, power input, energy consumption, vibrations, size of the grinding product particles. It is crucial for assessment of grinding structure to include energy and environmental criteria, which after being introduced to the materials and elements optimization process, cause creation of new innovative ideas and structures as well as methods and processes. It provides the basis for competitiveness, development of enterprise and product innovation.

FUNCTIONAL CRITERIA FOR ASSESSMENT OF MULTI-DISC GRINDING PROCESS

\begin{tabular}{|c|c|}
\hline \multirow{4}{*}{$\begin{array}{l}\text { States, elements and the } \\
\text { structural relations }\end{array}$} & optimal loadings \\
\hline & optimal material \\
\hline & optimal stability \\
\hline & optimal ratios of respective quantities \\
\hline \multirow{4}{*}{$\begin{array}{l}\text { control of grinder operation } \\
\text { efficiency }\end{array}$} & advisability \\
\hline & minimum \\
\hline & autoregulation \\
\hline & dependence of storeys and levels \\
\hline \multirow{4}{*}{$\begin{array}{l}\text { Control of grinding product } \\
\text { quality }\end{array}$} & optimal model \\
\hline & optimal consistence with the model \\
\hline & optimal product quality \\
\hline & optimal quality relations \\
\hline \multirow{4}{*}{$\begin{array}{l}\text { The mill operation impact } \\
\text { on the envirpnment }\end{array}$} & maintenance of the initial potential \\
\hline & minimization of the functional potential \\
\hline & minimization of waste \\
\hline & maximization of the recovered potential \\
\hline
\end{tabular}

Fig. 3. Functional criteria in assessment of multi disc grinding process 


\section{METHODS, TOOLS AND TECHNOLOGIES IN DESIGN OF GRINDERS}

Technological progress facilitates scientific research with the use of new methods, tools and technologies. Widespread use of computers and IT systems provides researchers with unlimited research possibilities in the form of modern methodological tools, e.g. computer simulation programs, supporting data analysis.

In the first stage - conception, construction of biomass grinders elements, the methods of computer aided design seem to be the most important, mainly in the field of creation of flat and spatial models and structure of the grinding system (tab. 1). Geometric features identified in this phase have the most important influence on grinding movement and the process parameters. In the second stage of verification, mathematical and simulation techniques are used for simulation of optimization of construction, e.g. be means of the finite elements method (MES). Application of computer programs in design allows to provide more accurate calculation results, shortening the time of the product creation, technological process while maintaining required parameters and saving resources and energy (Zaborski and Tubielewicz, 2007).

Table 1.

Methods, tools and techniques in particular stages of grinder design.

\begin{tabular}{|c|c|c|c|c|}
\hline STAGE & Stage of design & Methods & Tools & Techniques \\
\hline $\begin{array}{c}\text { I } \\
\text { conception }\end{array}$ & $\begin{array}{l}\text { Development of } \\
\text { construction of } \\
\text { elements }\end{array}$ & $\begin{array}{l}\text { Modeling 2D } \\
\text { and 3D }\end{array}$ & $\begin{array}{l}\text { AutoCad, } \\
\text { Inventor, } \\
\text { Solidworks } \\
\text { CATIA V5 }\end{array}$ & $\begin{array}{l}\text { Computer Aided } \\
\text { Design }\end{array}$ \\
\hline \multirow{5}{*}{$\begin{array}{c}\text { II } \\
\text { verification }\end{array}$} & \begin{tabular}{|l|} 
Strength \\
verification of \\
elements \\
\end{tabular} & $\begin{array}{l}\text { Finite } \\
\text { Elements } \\
\text { Method (FEM) }\end{array}$ & $\begin{array}{l}\text { ANSYS, } \\
\text { Inventor, MSC } \\
\text { Appex, }\end{array}$ & $\begin{array}{l}\text { Numerical } \\
\text { calculations }\end{array}$ \\
\hline & $\begin{array}{l}\text { Environmental } \\
\text { verification of } \\
\text { elements }\end{array}$ & Method CML & $\begin{array}{l}\text { Solidworks } \\
\text { Sustainability }\end{array}$ & $\begin{array}{l}\text { Assessment of } \\
\text { the } \\
\text { environmental } \\
\text { impact }\end{array}$ \\
\hline & $\begin{array}{l}\text { Dynamic and } \\
\text { kinematic } \\
\text { verification of the } \\
\text { structure }\end{array}$ & $\begin{array}{l}\text { Simulation of } \\
\text { dynamics of } \\
\text { many } \\
\text { elements }\end{array}$ & $\begin{array}{l}\text { MSC Adams, } \\
\text { Ansys }\end{array}$ & $\begin{array}{l}\text { Numerical } \\
\text { modeling }\end{array}$ \\
\hline & $\begin{array}{l}\text { Verification of the } \\
\text { process } \\
\text { parameters } \\
\text { operation }\end{array}$ & $\begin{array}{l}\text { Method of } \\
\text { discrete } \\
\text { elements } \\
\text { (DEM) }\end{array}$ & $\begin{array}{l}\text { Rocky DEM, } \\
\text { EDEM } \\
\text { BulkSim }\end{array}$ & $\begin{array}{l}\text { Numerical } \\
\text { modeling }\end{array}$ \\
\hline & $\begin{array}{l}\text { Environmental } \\
\text { verification of a } \\
\text { machine in its life } \\
\text { cycle }\end{array}$ & $\begin{array}{l}\text { Method } \\
\text { Ecoinvent, } \\
\text { Eco-index 99, } \\
\text { IPCC, CML }\end{array}$ & $\begin{array}{l}\text { SimaPro, } \\
\text { Gabi, Open } \\
\text { LCA }\end{array}$ & $\begin{array}{l}\text { Assessment of } \\
\text { the } \\
\text { environmental } \\
\text { impact }\end{array}$ \\
\hline$\frac{\text { III }}{\text { Compatibilization }}$ & $\begin{array}{l}\text { Adaptive } \\
\text { connection of } \\
\text { modules: process, } \\
\text { control and } \\
\text { logistics } \\
\end{array}$ & $\begin{array}{l}\text { Moduły SQL, } \\
\text { AbaquS, } \\
\text { genetic } \\
\text { algorithms }\end{array}$ & LABVIEW & $\begin{array}{l}\text { Artificial } \\
\text { intelligence }\end{array}$ \\
\hline $\begin{array}{c}\text { IV } \\
\text { Documentation }\end{array}$ & $\begin{array}{l}\text { Preparation of } \\
\text { executive } \\
\text { documentation }\end{array}$ & Modeling 2D & $\begin{array}{l}\text { AutoCad, } \\
\text { Inventor, } \\
\text { Solidworks } \\
\text { CATIA V5 } \\
\end{array}$ & $\begin{array}{l}\text { Computer Aided } \\
\text { Design }\end{array}$ \\
\hline
\end{tabular}

Source: own work 
Computer aided design is equally important at the stage of construction of devices and machine systems. It enables performance of analyses of the relations between elements and kinematic analyses as well as estimation of loadings. Simulation of a device operation enables optimization of geometric parameters, determination of strains and stresses affecting the machine elements. Currently used design systems are equipped with modules which allow to review several possible structural solutions, in dependence on the accepted criteria, thanks to which contribute to the quality and reliability of the product (Zaborski and Tubielewicz, 2007).

\section{DESIGN OF GRINDERS CONSIDERING SUSTAINABLE DEVELOPMENT}

The postulated operational states of grinding: quality, efficiency, and nondestructiveness fit in the sustainable development assumptions. Figure 4 shows a procedure to be used for a design of the grinding process in terms of sustainable development.

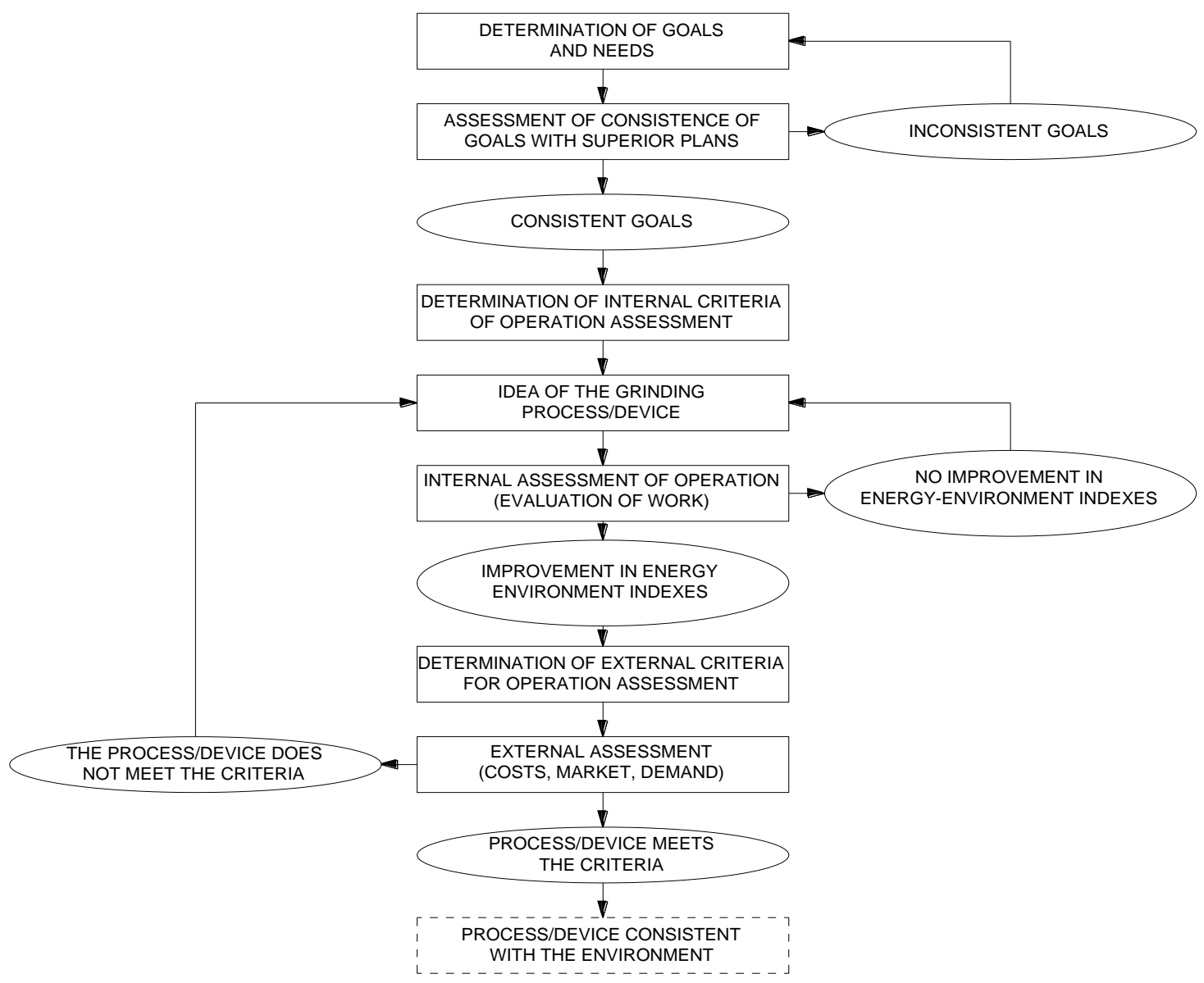

Fig. 4. Scheme of designing the proces/product consistent with the environment

Procedures for a design of the grinding process according to the assumptions of sustainable development, clean production in consistence with the environment allow to provide solutions characterized by the lowest energy consumption and higher nondestructiveness of impacts than other, so far used structures. In the light of current trends and the EU legislation, design of grinding processes and devices should be based on a model of sustainable production and consumption, according to figure 5 . Sustainable design of grinders should, then, take into consideration flows of energymaterial throughout the life cycle, beginning with the system creation (supply of 
energy and resources), through operation/maintenance (effects, entrance into the environment: the product of grinding, emissions in the form of gas, solid waste, liquid waste and other impacts, e.g. social), until its liquidation.

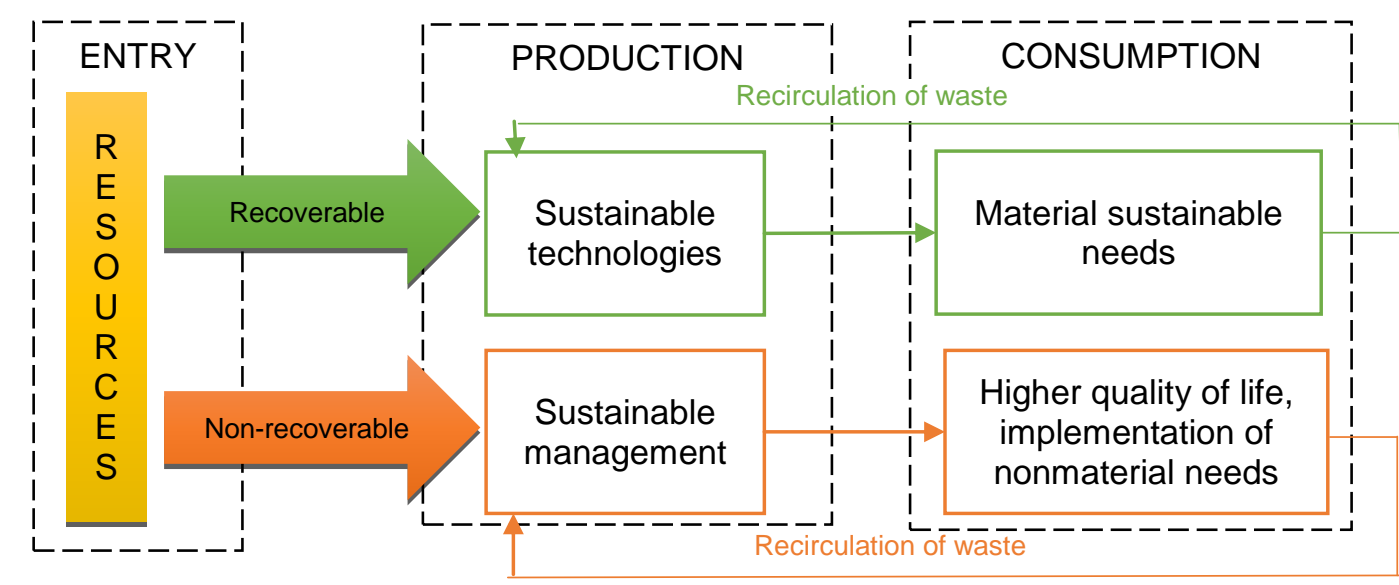

Fig. 4. Scheme o of sustainable production and consumption model on the example of a grinding system. Own work based on (Kwiatkowski, 2017)

\section{CONCLUSIONS}

The study goal has been achieved through development of an original methodology for the design of grinding machines, including external factors and their impacts, in order to increase energy, economic and ecological efficiency.

It is possible to find much information and data which can provide the basis for improvement in structural solutions of grinders, especially the multi-disc ones. The results of the research on processes and structures (CAD, SOLID EDGE) enable observation of changes in strength of the designed object packets, aided by the research on materials and provide the basis for drawing conclusions on the subject of innovation. The aim of the above mentioned method is improvement of the quality of direct solutions and constant search for the form (optimal) ideal, from the point of energy life cycle, and justified in terms of practical implementation.

The concept of aided design is understood as a constant quest for improvement of the materials grinding process energy efficiency. Aided design can be carried out on many levels of innovation. Modification of models minimizes the energy input into the process of innovation and energy used by a nonoptimal device, in terms of manufacturing efficiency, and is expressed by a set of structural features. Analysis of mechanical dependencies supports and completes this picture with necessary aspects of dynamic variability. At the same time, innovation is aided by creative inferring, e.g. use of computer simulation.

\section{ACKNOWLEDGEMENTS}

Scientific work financed by the budget resource for science in 2017-2021, as a research project under the "Diamentowy Grant" program.

\section{REFERENCES}

Dabbour, M. I., Bahnasawy, A., Ali, S., El-Haddad, Z., 2015. Grinding Parameters and Their Effects on the Quality of Corn for Feed Processing. Journal of Food Processing \& Technology, 6(9), 1-7. https://doi.org/10.4172/2157-7110.1000482. 
Flizikowski, J., Topoliński, T., Opielak, M., Tomporowski, A., Mroziński, A., 2015a. Research and analysis of operating characteristics of energetic biomass mikronizer. Eksploatacja i Niezawodność, 17(1), 19-26.

Flizikowski, J., Sadkiewicz, J., Tomporowski, A., 2015b. Functional Characteristics of a Six-Roller Mill for Grainy or Particle Materials Used in Chemical and Food Industries. Przemysł Chemiczny, 94(1), 69-75. DOI: 10.15199/62.2015.1.9.

Flizikowski, J., Wełnowski, J., Dudziak, P., 2017. Analysis end eco-technological evaluation of micro-grain supersonic milling. Part $I$. Models and indicators. Chemical Engineering and Equipment, 56(5), 161-63.

Fuerstenau, D.W, Abouzeid, A.-Z. M., 2002. The energy efficiency of ball milling in comminution. International Journal of Mineral Processing, 67(1), 161-85. DOI: 10.1016/S0301-7516(02)00039-X.

Fuerstenau, D.W., Kapur, P.C., Gutsche, O., 1993. Comminution of single particles in a rigidly-mounted roll mill part 1: mill torque model and energy investment. Powder Technology, 76(3), 253-62, DOI: 10.1016/S0032-5910(05)80006-3.

He, B., Luo, T., Huang, S., 2019. Product sustainability assessment for product life cycle. Journal of Cleaner Production, 206, 238-50. DOI: 10.1016/j.jclepro.2018.09.097.

Jeswiet, J., Szekeres, A., 2016. Energy Consumption in Mining Comminution. Procedia CIRP, 48, 140-45. DOI: 10.1016/j.procir.2016.03.250.

Kwiatkowski, D., 2017, Komputerowe wspomaganie projektowania materiałowego. http://www.planrozwoju.pcz.pl/wyklady/mechatronika/Komputerowe_wspomaganie _projektowania_materialowego_w.pdf.

Macko, M., Flizikowski, J., Szczepański, Z., Tyszczuk, K., Śmigielski, G., Mroziński, A., Czerniak, J., Tomporowski. A., 2016. CAD/CAE Applications in Mill's Design and Investigation. Proceedings of the 13th International Scientific Conference, Springer, Cham, 343-51, DOI: 10.1007/978-3-319-50938-9_35.

Napier-Munn, T., 2015. Is progress in energy-efficient comminution doomed? Minerals Engineering, 73, 1-6. DOI: 10.1016/j.mineng.2014.06.009.

Silvestre, B.S., Tîrcă, D.M., 2019. Innovations for sustainable development: Moving toward a sustainable future. Journal of Cleaner Production, 208, 325-332. DOI: 10.1016/j.jclepro.2018.09.244.

Tomporowski, A., Flizikowski, J., Kruszelnicka, W., 2017. A new concept of rollerplate mills. Przemysł Chemiczny, 96(8), 1750-1755. DOI: 10.15199/62.2017.8.29.

Wołosiewicz-Głąb, M., Foszcz, D., Saramak, D., Gawenda, T., Krawczykowski, D., 2017. Analysis of a grinding efficiency in the electromagnetic mill for variable process and feed parameters. E3S Web of Conferences, 18, 01012, DOI: 10.1051/e3sconf/201712301012

Pan, Z., Amaratunga, K.S.P., Thompson, J.F., 2007. Relationship Between Rice Sample Milling Conditions and Milling Quality. Transactions of the ASABE, 50(4), 1307-1313, DOI: 10.13031/2013.23607.

Zaborski, A., Tubielewicz, K., 2007. Production preparation using computer systems. Biuletyn WAT, 56(SP1), 127-138.

Zhou, J., Li, P., Zhou, Y., Wang, G., Zang, J., Meng, L., 2018. Toward NewGeneration Intelligent Manufacturing. Engineering, 4(1), 11-20. https://doi.org/10.1016/j.eng.2018.01.002. 